\title{
Identification of low molecular weight nuclear complexes containing integrase during the early stages of HIV-1 infection
}

Annabelle Gérard ${ }^{1,2,3 \dagger}$, Nicolas Soler ${ }^{1,2,3 \dagger}$, Emmanuel Ségéral ${ }^{1,2,3}$, Michael Belshan ${ }^{4,5}$ and Stéphane Emiliani $1^{1,2,3^{*}}$

\begin{abstract}
Background: HIV-1 replication requires integration of its reverse transcribed viral cDNA into a host cell chromosome. The DNA cutting and joining reactions associated to this key step are catalyzed by the viral protein integrase (IN). In infected cells, IN binds the viral CDNA, together with viral and cellular proteins, to form large nucleoprotein complexes. However, the dynamics of IN complexes formation is still poorly understood.

Results: Here, we characterized IN complexes during the early stages of T-lymphocyte infection. We found that following viral entry into the host cell, IN was rapidly targeted to proteasome-mediated degradation. Interactions between IN and cellular cofactors LEDGF/p75 and TNPO3 were detected as early as $6 \mathrm{~h}$ post-infection. Size exclusion chromatography of infected cell extracts revealed distinct IN complexes in vivo. While at $2 \mathrm{~h}$ post-infection the majority of IN eluted within a high molecular weight complex competent for integration (IN complex I), IN was also detected in a low molecular weight complex devoid of full-length viral cDNA (IN complex II, $\sim 40 \mathrm{KDa}$ ). At $6 \mathrm{~h}$ post-infection the relative proportion of IN complex II increased. Inhibition of reverse transcription or integration did not alter the elution profile of IN complex II in infected cells. However, in cells depleted for LEDGF/p75 IN complex II shifted to a lower molecular weight complex (IN complex III, 150 KDa) containing multimers of IN. Notably, cell fractionation experiments indicated that both IN complex II and III were exclusively nuclear. Finally, IN complex II was not detected in cells infected with a virus harboring a mutated IN defective for LEDGF/p75 interaction and tetramerization.
\end{abstract}

Conclusions: Our findings indicate that, shortly after viral entry, a significant portion of DNA-free IN that is distinct from active pre-integration complexes accumulates in the nucleus.

Keywords: Human immunodeficiency virus, Integrase, Pre-integration complex, LEDGF/p75

\section{Background}

During the early stages of retroviral replication, the virus travels from the cellular plasma membrane across the nuclear pore to finally integrate its viral cDNA into the host cell genome. These early events first require the reverse transcription of the viral RNA into a linear double strand cDNA copy by the viral reverse transcriptase (RT). Once synthesized, this cDNA becomes part of a large nucleoprotein complex, called the pre-integration complex (PIC) (reviewed in [1]). PICs from Moloney

\footnotetext{
* Correspondence: stephane.emiliani@inserm.fr

'Equal contributors

'Inserm, U1016, Institut Cochin, Paris, France

${ }^{2}$ Cnrs, UMR8104, Paris, France

Full list of author information is available at the end of the article
}

murine leukemia virus (MLV) [2-4] or Human immunodeficiency virus (HIV) [5-7] can be partially purified after cell infection and can efficiently integrate their associated reverse transcribed viral cDNA into heterologous DNA targets in vitro [8]. The integration reaction is mediated by the retroviral integrase (IN) [9-11]. Within the PIC, IN binds to viral cDNA ends [12-14] and catalyzes the DNA cutting and joining reactions. First, the 3 ' processing reaction consists in the hydrolysis of a dinucleotide at each end of the viral cDNA $[4,15,16]$. Then, exposed recessed 3' hydroxyl groups of the viral cDNA are joined to the $5^{\prime}$ ends of the cut host target DNA [4-6,15]. At this stage, cellular enzymes are probably in charge of removing the $5^{\prime}$ unpaired viral DNA ends and subsequently catalyze the gap filling and

\section{Biomed Central}


ligation reactions of host-viral DNA junctions [17]. Human immunodeficiency virus type-1 (HIV-1) integration produces a $5 \mathrm{bp}$ duplication of the DNA host sequence at each end of the integrated provirus [18].

Retroviral PICs are large nucleoprotein complexes that contain several viral and cellular proteins in addition to IN and viral cDNA. Biochemical studies indicate that HIV-1 PICs contain the viral nucleocapsid (NC), matrix (MA), Vpr and RT proteins [19-25]. In contrast with MLV [2,26], HIV-1 PICs were shown to be devoid of CA [19-25]. In addition, cellular proteins including barrier to auto-integration factor (BAF), high mobility group protein HMGA, Ku and LEDGF/p75 have been found to associate with partially purified HIV-1 PICs [20,27-29].

HIV and other lentiviruses have the ability to infect non-dividing cells, such as terminally differentiated macrophages. Therefore, this large viral nucleoprotein complex $(>50 \mathrm{~nm})$ must pass through the nuclear pore with the active participation of cellular factors involved in nucleo-cytoplasmic shuttling. Although several viral proteins within the HIV-1 PIC contain karyophilic signals (MA, Vpr and IN), their exact role during PIC translocation into the nucleus is still controversial [30]. The central polypurine track (cPPT), a cis-acting sequence that forms a short triple stranded DNA structure (the central DNA Flap) during reverse transcription, is also implicated in the nuclear import of HIV PICs [31,32]. Importantly, reports show that the HIV-1 capsid (CA) is the dominant viral determinant for HIV-1 infection of non-dividing cells, and the kinetic of dissociation of CA from the viral core appears to be a critical step in controlling nuclear import $[33,34]$.

Among the HIV-dependency factors involved in HIV-1 replication, TNPO3 was recently shown to be involved in a nuclear import and/or preintegration step [35-40]. TNPO3 is a karyopherin from the importin- $\beta$ family that mediates transport of serine/arginine rich (SR) proteins into the nucleus in a phosphorylation-dependent manner [41]. Using yeast two-hybrid screenings, we identified TNPO3 as a binding partner of IN $[36,42]$. Although a direct interaction between HIV-1 IN and TNPO3 has been clearly established $[36,43,44]$, recent reports indicated that HIV CA is one of the viral determinants important for TNPO3 requirement $[8,38-40,44,45]$.

Once inside the nucleus, IN catalyzes viral cDNA integration into the genome of the host cell $[46,47]$. HIV-1 integration occurs preferentially in transcription units (TUs) of transcriptionally active genes whereas CpG islands and promoter regions are disfavored. Importantly, the targeting of viral integration to specific regions of the host chromosome is under the control of LEDGF/ p75 [48-50]. LEDGF/p75 is a key factor of HIV-1 integration that was identified as an IN interacting factor [51-53]. LEDGF/p75 is a cellular chromatin-associated protein presumably involved in transcriptional regulation of cellular genes [54-56]. LEDGF/p75 is tightly associated to chromatin, and the molecular basis of this interaction involves its conserved PWWP and AT-hook domains in the $\mathrm{N}$-terminal region of the protein $[57,58]$. LEDGF/p75 plays an important role in lentiviral cDNA integration, as demonstrated by mutagenesis [52,59-61], over-expression of LEDGF/p75 IBD (Integrase Binding Domain) $[62,63]$ as well as RNAi and knock-out studies [49,50,62-65]. Structural studies revealed the roles of both the catalytic core domain dimeric interface and the $\mathrm{N}$-terminal domain of IN for high affinity binding to IBD $[60,66,67]$. Albeit not strictly essential for replication, LEDGF/p75 tethers PIC-associated IN to chromatin to presumably stimulate its enzymatic activity at the site of integration $[57,58]$.

In this study, we explored at early times post infection the dynamics of interaction between IN and its cellular and viral partners. However, the detection of IN in infected cells remains technically challenging. We took advantage of a previously characterized virus carrying an active tagged-IN with the HA epitope at the C-terminus [68] to purify and characterize IN complexes in the context of infected lymphocytes. Our results shed light on the stability and distribution of IN during early steps of HIV-1 infection. We show that IN is rapidly degraded in a proteasome-dependent manner upon virus entry into the cell. Immunoprecipitation experiments allowed us to detect interactions between IN and its cofactors LEDGF/ p75 and TNPO3 at $6 \mathrm{~h}$ post-infection (p.i.). Using size exclusion chromatography, we uncover that IN exists in at least two distinct complexes in infected cells: a high molecular weight complex that co-fractionates with viral cDNA and integration activity, and a low molecular weight complex devoid of viral cDNA that is found exclusively in the nucleus and depends on LEDGF/p75 expression.

\section{Results}

HIV-1 integrase is rapidly degraded in a proteasomedependent manner upon cell infection

To facilitate HIV-1 integrase detection during the course of cell infection, we took advantage of an infectious HIV-1 viral clone carrying IN tagged at the C-terminus with the HA epitope (HIV-1 $1_{\mathrm{IN}-\mathrm{HA}}$ [68]). Epitope fusion at the $\mathrm{C}$-terminus of IN disrupted the Vif open reading frame. However, viral replication is Vif-independent in SupT1 human lymphocytic cells used in our study [69]. Using this virus, we first analyzed IN stability during the early steps of HIV-1 replication. Indeed, the ubiquitin degradation pathway targets IN to the proteasome [70], which may account for its short half-life in transiently transfected cells $[70,71]$. SupT1 cells were exposed to HIV-1 for $2 \mathrm{~h}$ and harvested at $2 \mathrm{~h}, 4 \mathrm{~h}$ and $6 \mathrm{~h}$ p.i. At 
each time whole cell extracts (WCE) were prepared and viral proteins $\mathrm{CA}, \mathrm{MA}$ and IN-HA were detected by Western blotting. By optimizing cell infection conditions in order to maximize cell-virus contact surface, incoming CA, MA and IN-HA were readily detectable in cell extracts of infected cells. Infection of cells with a heat inactivated virus prevented detection of viral proteins in cells extracts, indicating that we specifically detected intracellular-associated viral proteins rather than virus absorbed at the cell surface (Figure 1A). Strikingly, the amount of IN-HA dramatically decreased during the $6 \mathrm{~h}$ period of time, whereas amounts of CA remained stable (Figure 1A and 1B). To ensure that the HA-tag did not interfere with IN properties, we compared the stability of HA-tagged and non-tagged IN proteins. SupT1 cells were infected either with wild type HIV-1 or HIV-1 $1_{\text {IN-HA, }}$ and IN was detected in cell lysates at different times postinfection using an anti-IN antibody. Regardless of the presence of a C-terminus HA-tag fusion, IN levels in cell lysates rapidly decreased to become barely detectable at $6 \mathrm{~h}$ p.i. (Figure 1B). In addition, levels of late reverse transcription product (LRT), 2-LTR circles and integrated viral DNA were similar at $6 \mathrm{~h}$ p.i. for both viruses indicating that the HA tag does not interfere with IN functions during early steps of virus replication (data not shown). Treatment of cells with proteasome inhibitor MG-132 resulted in rapid stabilization of IN-HA in infected cells indicating that once IN entered in the cell, a subset of the protein is actively degraded in a proteasomedependent manner (Figure 1C). We further analyzed early steps of viral replication of HIV- $1_{\text {IN-HA }}$. Quantitative PCR analysis indicated that the maximum amount of integrated provirus was reached at $10 \mathrm{~h}$ p.i (Figure 1D). Taken together, our results showed rapid degradation of IN protein upon cell infection, coinciding with detection of integrated proviral forms at $6 \mathrm{~h}$ p.i. Therefore, we decided to focus our study on early time points (i.e. $2 \mathrm{~h}$ p.i. and $6 \mathrm{~h}$ p.i.) to monitor the dynamic of IN-containing complexes.

\section{Dynamic distribution of HIV-1 integrase complexes during infection}

The temporal dynamic of IN interactions with cellular cofactors during early steps of HIV replication was characterized by co-immunoprecipitation experiments. Interactions between IN-HA and host partners TNPO3 and

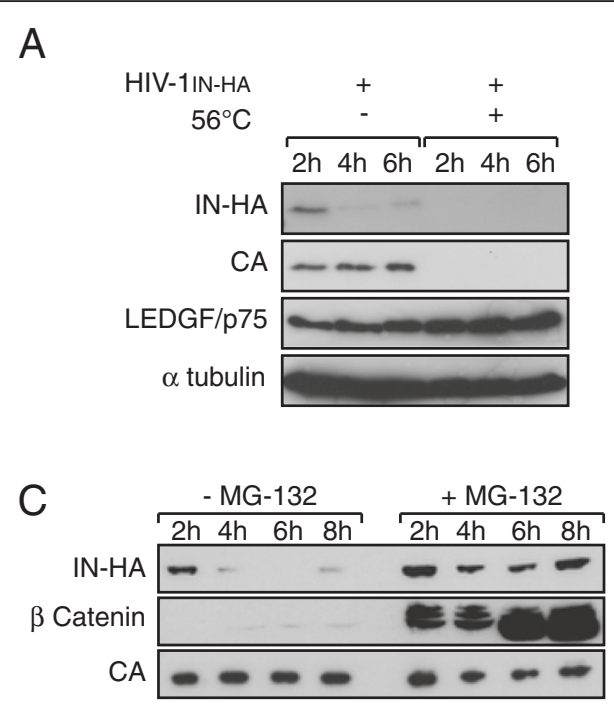

B
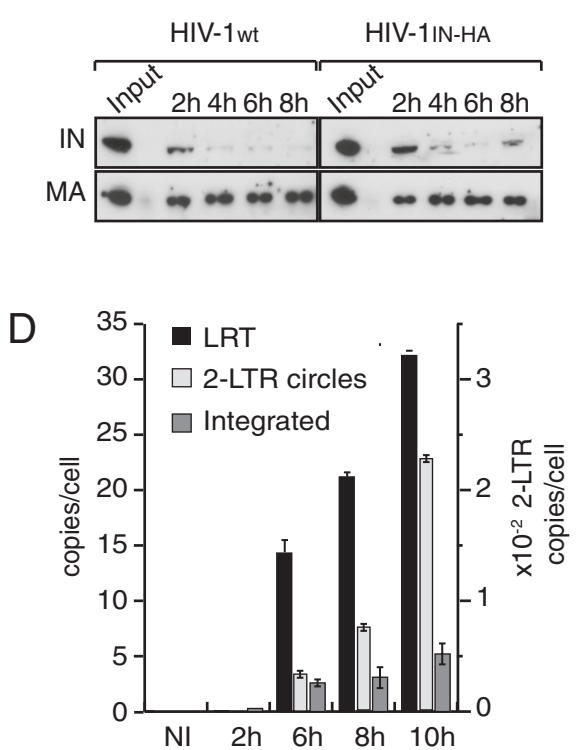

Figure 1 IN is rapidly degraded in a proteasome-dependent manner during early steps of HIV-1 replication. (A) SupT1 cells were

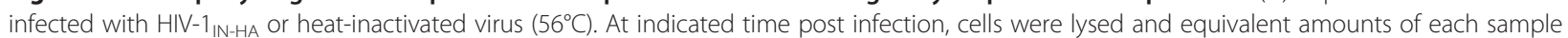
(100 $\mathrm{\mu g}$ of protein) were analyzed using Western blotting with antibodies against HA, CA, LEDGF/p75 and a-tubulin as loading control. (B) Both IN-HA and non-tagged IN are rapidly degraded following viral entry into the cell. SupT1 cells were infected with HIV-1 IN-HA $_{\text {Or HIV-1 }}$ wt. At indicated time post infection, cells were lysed and equivalent amounts of each sample (100 $\mathrm{\mu g}$ of protein) were analyzed using Western blotting with antibodies against IN and MA. Input represents $0.1 \%$ of the amount of virus used to infect the cells. (C) IN is targeted to proteasomal degradation following infection of the cells. SupT1 cells were infected with HIV-1 $1_{\text {N-HA }}$ in absence or presence of proteasome inhibitor MG-132. As in (B), cell lysates were analyzed by Western blotting with antibodies against HA, $\beta$-Catenin and CA. $\beta$-Catenin was used as a control to monitor

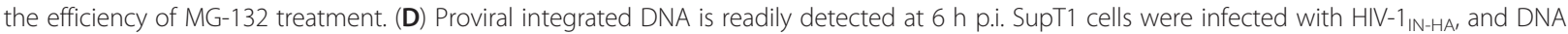
was extracted at indicated time post infection. Late reverse transcription product (LRT), 2-LTR circles and integrated viral DNA were quantified by real time PCR. 
LEDGF/p75 were readily detected at $6 \mathrm{~h}$ p.i. (Figure 2). To further assess the rapid changes of IN-associated complexes during the early stages of HIV-1 replication, we performed biochemical fractionation of infected cell lysates. First, fractions from size-exclusion chromatography of WCE were analyzed by Western blotting against TNPO3 and LEDGF/p75. In non-infected cells, the relatively broad elution profile of TNPO3 might reflect its interactions with several different proteins/ cargos (fractions 17 to 33, Figure 3A). In contrast, a major peak around 300 KDa (Fractions 22-28, Figure 3A) was observed for LEDGF/p75. In addition, a small portion of LEDGF/p75 was found in higher molecular weight fractions (fractions 17-19, Figure 3A).

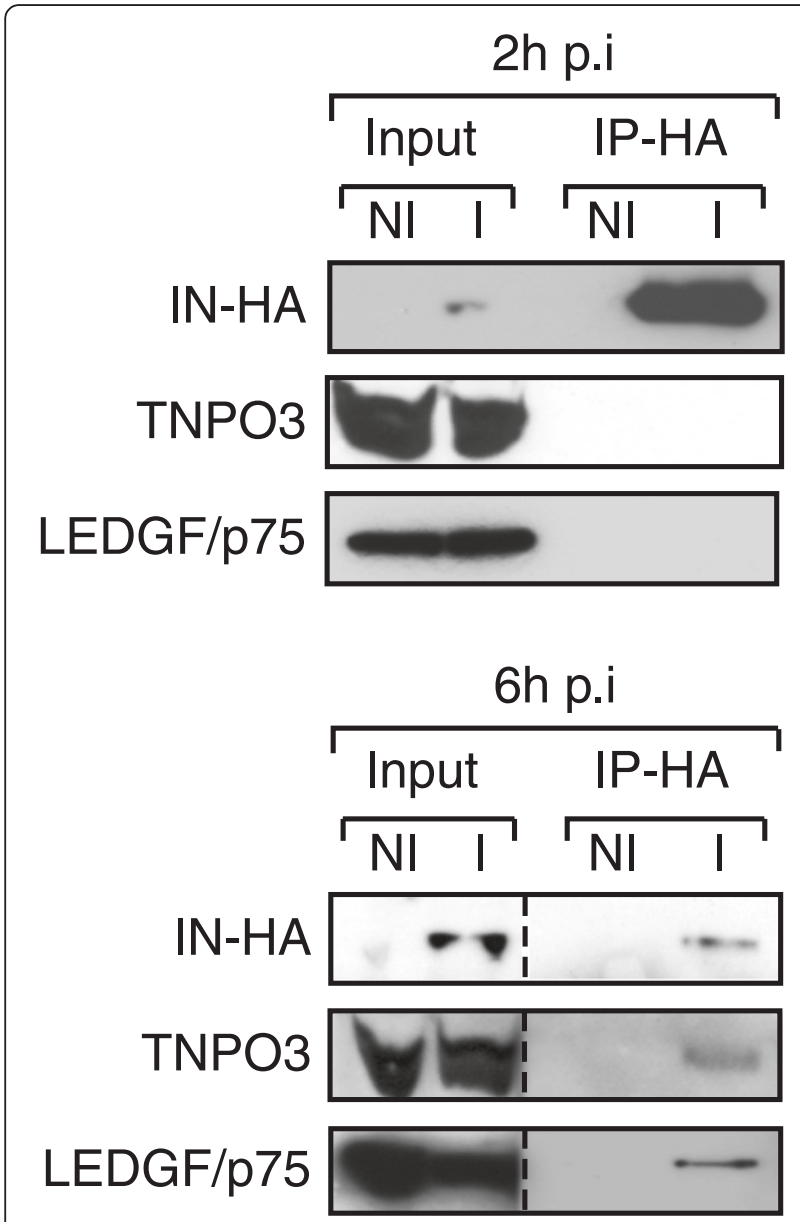

Figure 2 IN interacts with cellular cofactors LEDGF/p75 and TNPO3 at 6 h p.i. SupT1 cells were not infected (NI) or infected (I)

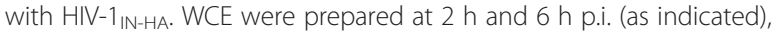
immunoprecipitated (IP-HA) with the anti-HA affinity matrix and analyzed by Western blotting using antibodies against HA, LEDGF/ p75, and TNPO3. Inputs represent 5\% of the immunoprecipitated material. To detect IN-HA at $2 \mathrm{~h}$ p.i. the film was exposed for 5 minutes whereas detection of $\mathrm{IN}-\mathrm{HA}$ at $6 \mathrm{~h}$ p.i. required film exposure of 30 minutes. Dividing lines indicate the grouping of parts of the same gel.
Similar profiles were observed in infected cells (data not shown), indicating that HIV-1 infection does not trigger major changes in the distribution of LEDGF/p75 or TNPO3-associated complexes.

We then addressed the distribution of viral proteins early following infection. At $2 \mathrm{~h}$ p.i., IN-HA was detected in 2 complexes of different size and composition (Figure 3B). The high molecular weight complex (IN complex I), which was excluded from gel separation range $(>1.3 \mathrm{MDa})$, was the most abundant one (fractions 15-18, Figure 3B). Viral proteins capsid (CA) and matrix (MA) were mostly found as free molecules (fractions 36-44, Figure $3 \mathrm{~B}$ and $\mathrm{C}$ ), except for a small proportion co-eluting with IN complex I (fractions 15-17 for CA and fraction 17-20 for MA, Figure 3B).

Although present in a minor proportion, low molecular weight (IN complex II) IN-HA complex peaked in fractions 23-25 (around $440 \mathrm{KDa}$ ). At $6 \mathrm{~h}$ p.i., IN-HA was still found in IN complex I, but shifted readily to IN complex II, while both CA and MA were only detected in smaller peaks (fraction 36-44) (Figure 3C). Noteworthy, IN-HA detection required longer exposure times at $6 \mathrm{~h}$ than at $2 \mathrm{~h}$ p.i., due to its rapid degradation upon cell infection. Together, our results indicate that shortly after infection, IN associates with at least two distinct complexes.

IN low molecular weight complexes are devoid of viral DNA and in vitro PIC activity

To detect viral DNA potentially associated with IN complexes at these time points, we performed real-time PCR on DNA extracted from fractionated WCE (Figure 3D). At $2 \mathrm{~h}$ and $6 \mathrm{~h}$ p.i., viral DNA was detected in fractions 13 to 19 containing the IN complex I (Figure 3D). Elution of the viral cDNA in the void volume of the column $(>1.3 \mathrm{MDa})$ is consistent with its estimated molecular weight ( 6.4 MDa for the $9.7 \mathrm{kbp}$ genome). In vitro integration activities of IN-containing complexes eluted from the column were also measured at $6 \mathrm{~h}$ p.i.. To ensure optimal infection conditions, SupT1 cells were infected with VSV-G pseudotyped HIV-1 IN-HA and the ability of viral DNA to integrate into target plasmid in vitro was quantified by real-time PCR. Concomitant with the detection of viral DNA and IN in fractions containing complex I (Figure 4A and 4B), maximal PIC activity was also reached in these fractions (Figure $4 \mathrm{C}$ ). Thereby, these data suggest that between $2 \mathrm{~h}$ and $6 \mathrm{~h}$ p.i. a significant portion of IN accumulates in a low molecular weight complex devoid of viral DNA.

\section{Accumulation of IN complex II does not require reverse transcription nor integration but depends on LEDGF/p75 expression}

To assess the role of reverse transcription in the accumulation of IN complex II, fractionation of infected cell 


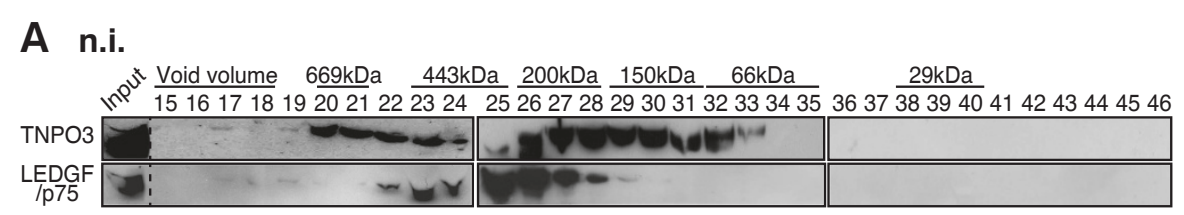

\section{B 2 h p.i.}

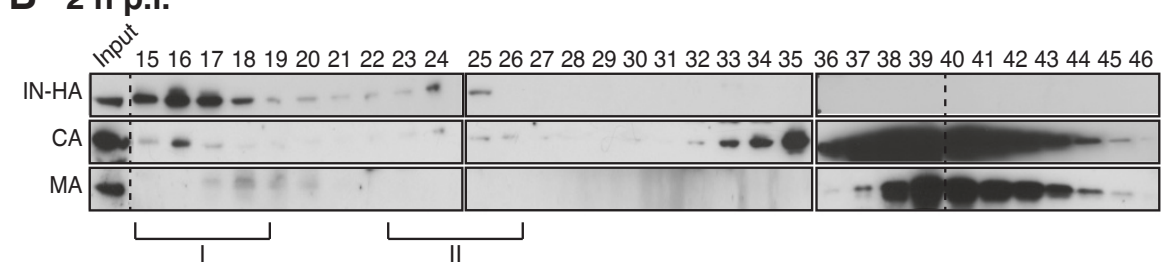

C 6 h p.i.

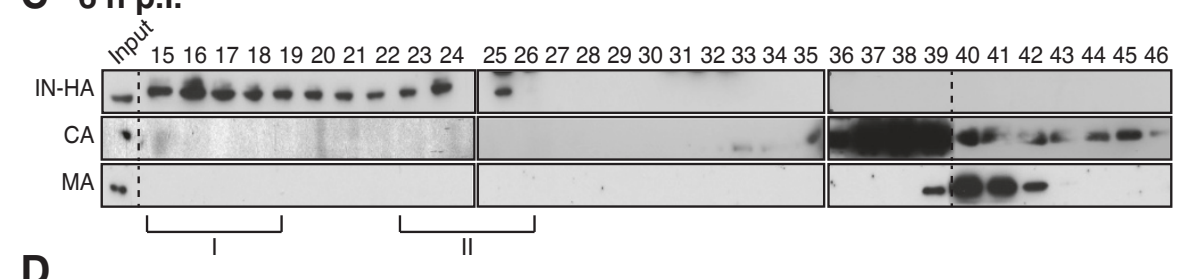

D

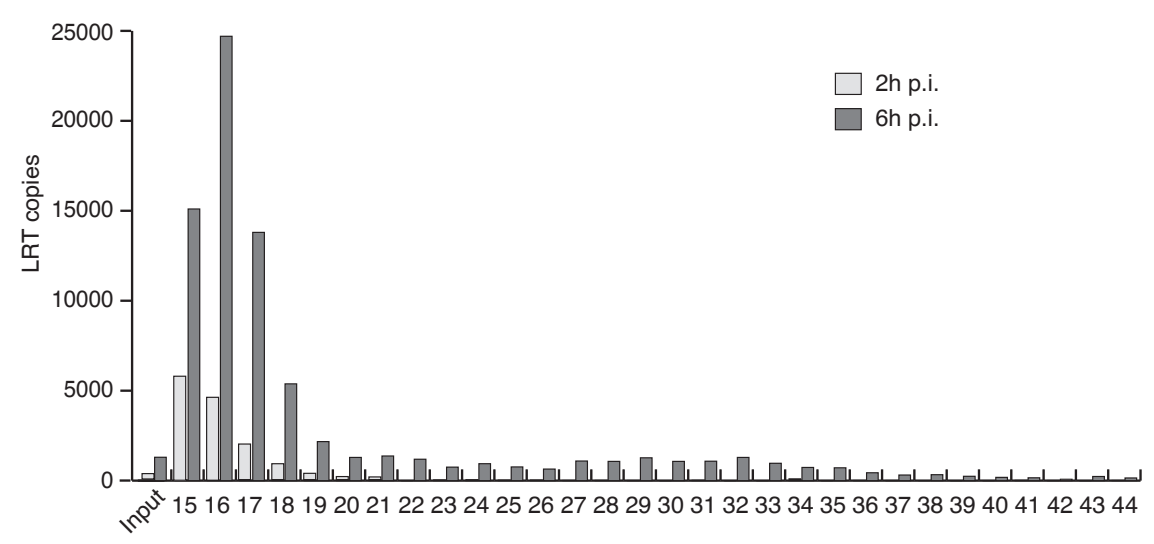

Figure 3 Two distinct IN complexes are detected following cell infection. SupT1 cells were either not infected (A) or infected with HIV-1 INHA, and WCE were prepared at $2 \mathrm{~h}$ (B) and $6 \mathrm{~h}$ p.i. (C). WCE were subjected to gel filtration on a Superdex 200HR 10/300 column. Fractions were collected and analyzed by Western blotting using antibodies against LEDGF/p75, TNPO3, HA, MA, and CA. Inputs represent 3.5\% of WCE load. Two complexes containing IN were detected, a high molecular weight complex (IN complex I, >1.3 MDa), and a low molecular weight complex (IN complex II, $\sim 440 \mathrm{KDa}$ ). To detect IN-HA at $2 \mathrm{~h}$ p.i. in (B), the film was exposed for 5 minutes, whereas detection of IN-HA at $6 \mathrm{~h}$ p.i. in (C) required film exposure of 30 minutes. (D) Viral DNA co-elutes with IN complex I. Same as (A) and (B) except DNA was extracted from each fraction and late reverse transcription product (LRT) content was quantified by real time PCR. Non-infected (NI) samples were used as controls (not shown). Results shown are representative of two independent experiments. Dividing lines indicate the grouping of parts of the different gels with identical times of film exposure.

extracts were conducted in the presence or absence of the non-nucleoside reverse transcriptase inhibitor Nevirapine. Nevirapine treatment did not affect the kinetics of IN degradation (Figure 5A). Furthermore, upon reverse transcription inhibition, IN was still detected in complex II (Figure 5B and 5C), suggesting that the accumulation of IN in low molecular weight complexes does not require the maturation of the reverse transcription complex (RTC) into a PIC.
Next, we tested whether IN complex II could be the result of a post-integration event leading to the release of DNA-free IN from integrated intasomes. SupT1 cells were infected with a virus harboring a catalytically inactivated $\mathrm{IN}_{\mathrm{D} 116 \mathrm{~A}}$. At $2 \mathrm{~h}$ p.i., cell extracts were fractionated by size exclusion chromatography and collected fractions were analyzed by Western blotting. IN from HIV-1 IN D116A-HA eluted in two separate complexes (I and II) that were indistinguishable from the complexes 


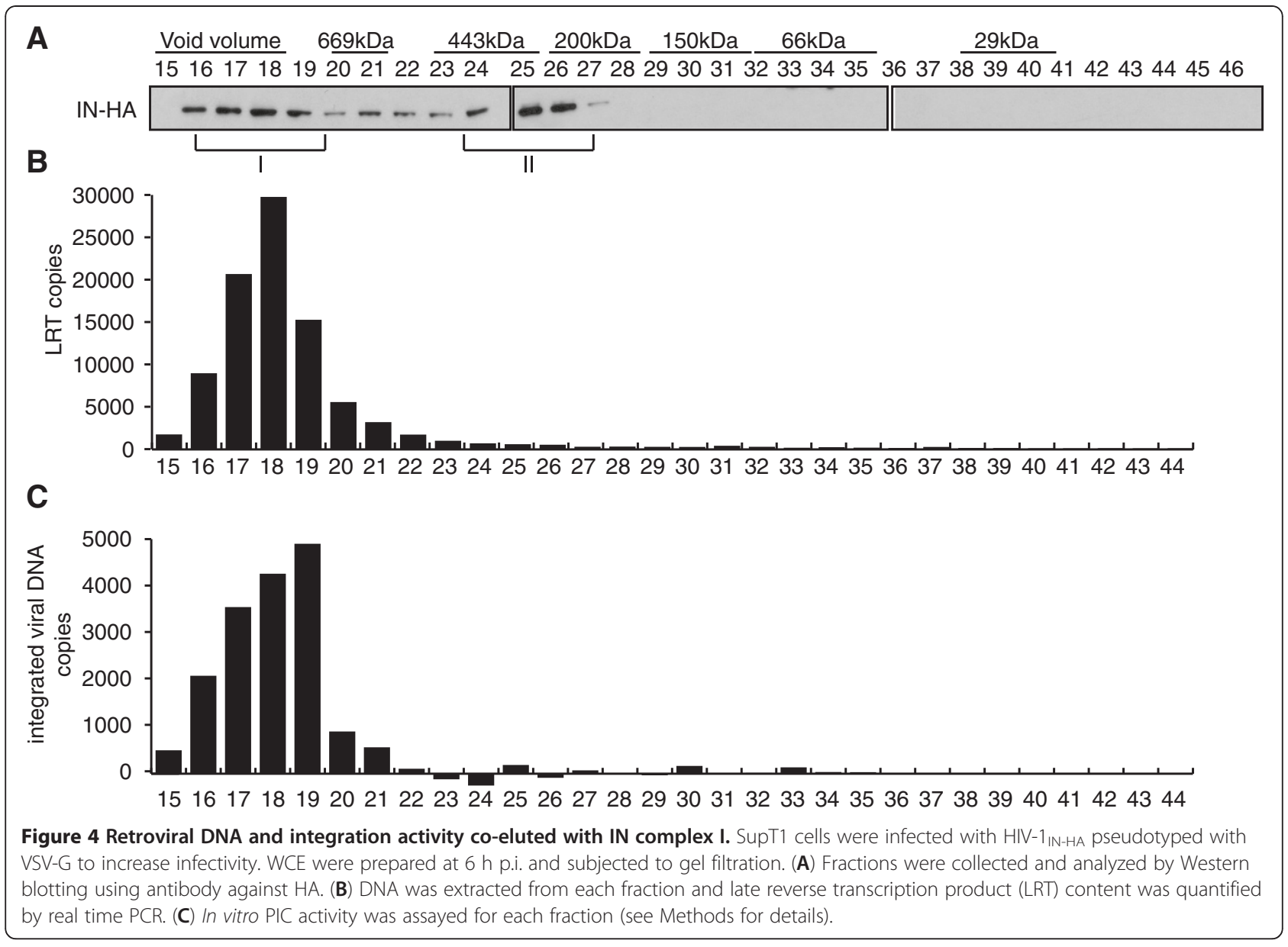

obtained with WT IN (Figure 6), indicating that accumulation of IN complex II is not a post-integration event.

We then investigated whether the distribution of the fractions containing IN was dependent on LEDGF/p75 expression. A LEDGF/p75-knock-down SupT1 cell clone (TL34) and its control polyclonal cell line counterpart (TC3) [72] were infected with VSV-G pseudotyped HIV$1 \Delta$ env-Luc. As expected, knock-down of endogenous LEDGF/p75 yielded a 10-fold decrease of viral infectivity, quantified by the viral encoded luciferase activity (Figure 7A). Then, WCE from TC3 or TL34 cells infected with $\mathrm{HIV}-1_{\mathrm{IN}-\mathrm{HA}}$ virus for $2 \mathrm{~h}$ were fractionated by size exclusion chromatography and collected fractions were analyzed by Western blotting. Consistently, we observed similar IN complexes (I and II) in TC3 lysates as in wild type SupT1 lysates (compare Figure 7B with 3B). In sharp contrast, in TL34 cells knocked down for LEDGF/p75 we observed a shift of IN complex II towards a lower molecular weight complex (IN complex III) with a molecular mass around $150 \mathrm{KDa}$ (fractions 27-31) (Figure 7C). Regarding the ability of IN to form stable tetramers when expressed in human cells [51], we decided to further characterize IN complex III. We thus pooled fractions 30-32 and performed proteins crosslinking with increasing amount of the cross-linker ethylene glycol bis-succinimidylsuccinate (EGS). Addition of 0.25 to $2 \mathrm{mM}$ of EGS yielded cross-linked complexes of 60,90 and $130 \mathrm{KDa}$, with a strong predominance of the latter band at the higher concentrations of cross-linker agent (Figure 7D). Thus, depletion of LEDGF/p75 led to the accumulation of IN complex III that contains tetramers of IN.

\section{IN complexes II and III are exclusively nuclear}

We analyzed the cellular localization of the IN complexes at $2 \mathrm{~h}$ p.i.. Cytosolic (CE) and nuclear extracts (NE) prepared from infected control (TC3) or LEDGF/ p75-knock-down SupT1 cells (TL34) were fractionated. LEDGF/p75 was only detected in nuclear fractions of control cells, indicative of absence of NE contamination of the CE (Figure 8A). In both TC3 and TL34 cells, IN complex I was distributed between cytosolic and nuclear fractions, indicating that PICs reached the nuclear compartment as early as $2 \mathrm{~h}$ p.i. (Figure $8 \mathrm{~A}$ and $8 \mathrm{~B}$ ). In sharp contrast, IN complex II was strictly associated with nuclear fractions and could not be detected in cytosolic 


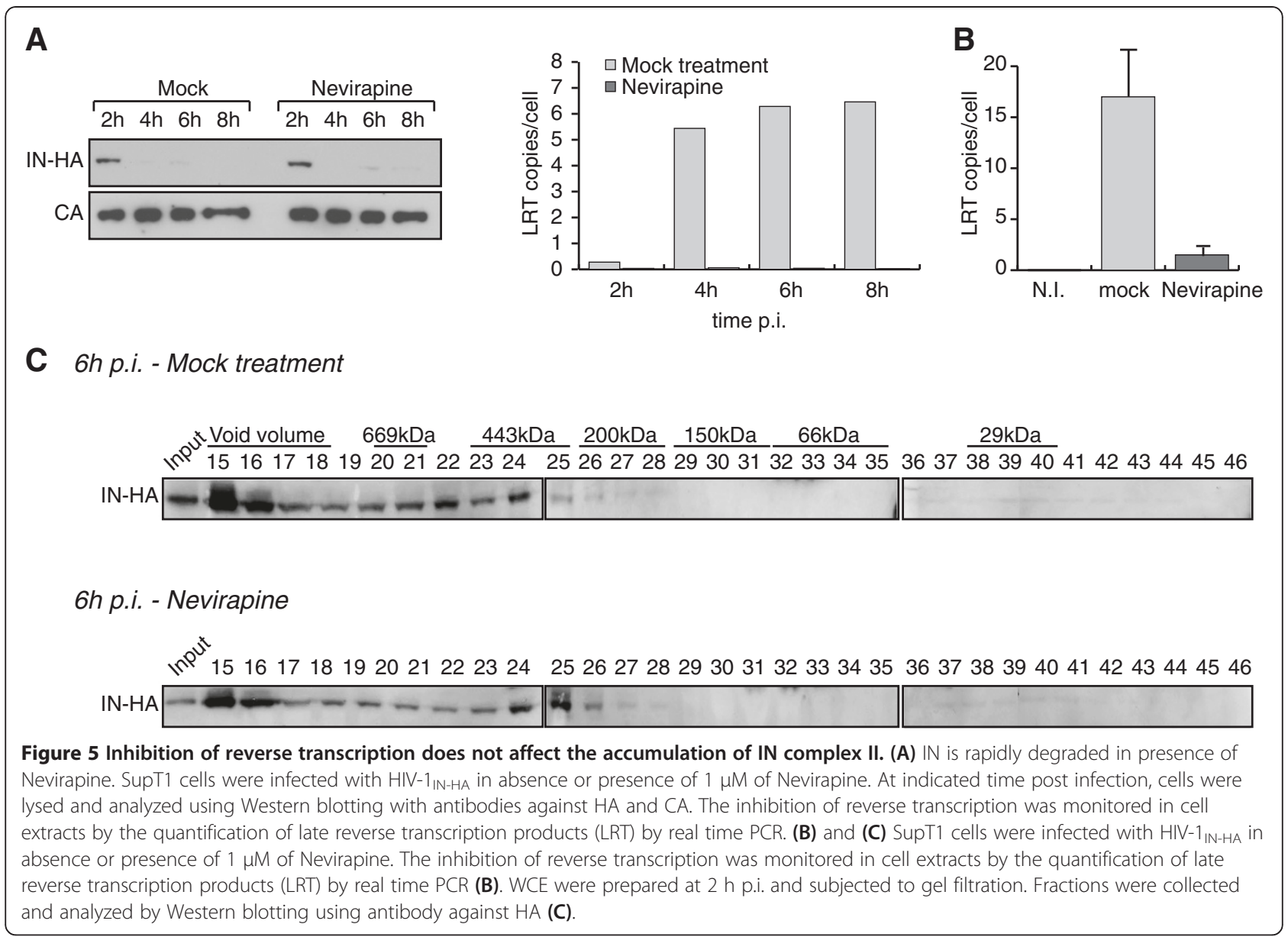

extracts of TC3 cells (Figure 8A). Concordantly, in absence of LEDGF/p75, IN complex III was also only detected in nuclear fractions (Figure 8B). Taken together, our data indicate that IN complex II associates with nuclear fractions in a LEDGF/p75-dependent manner.

\section{A class II IN mutant virus failed to accumulate in low molecular weight complexes}

To further explore the mechanisms of the accumulation of IN in low molecular weight complexes, we took advantage of an IN class II mutant virus HIV-1 ${ }_{\text {IN }}$ Q168AHA that was first identified to be defective for LEDGF/ p75 interaction [52]. Mutation of the Q168 residue of IN impairs its ability to form tetramers, resulting in a decrease of its concerted integration activity [43,73]. First, the stability of the mutant IN Q168A was assessed during infection. WCE from SupT1 cells infected with HIV-1 $1_{\text {IN }}$ Q168A-HA were harvested at $2 \mathrm{~h}, 4 \mathrm{~h}, 6 \mathrm{~h}$ and $8 \mathrm{~h}$ p.i. and viral proteins $\mathrm{MA}$ and IN were detected by Western blotting. $\mathrm{IN}_{\mathrm{Q} 168 \mathrm{~A}}$ levels decreased rapidly during the

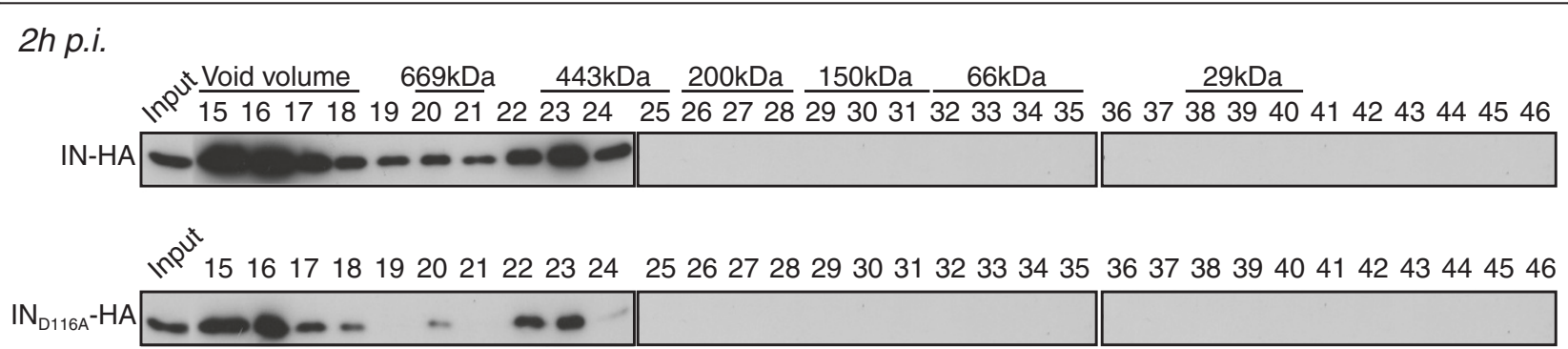

Figure 6 IN complex II does not require integration. SupT1 cells were infected with wild type HIV-1 IN-HA Or HIV-1 IN D116A-HA harboring a mutation of integrase active site residue Asp116. WCE were prepared at $2 \mathrm{~h}$ p.i. and subjected to gel filtration. Fractions were collected and analyzed by Western blotting using antibody against HA. 


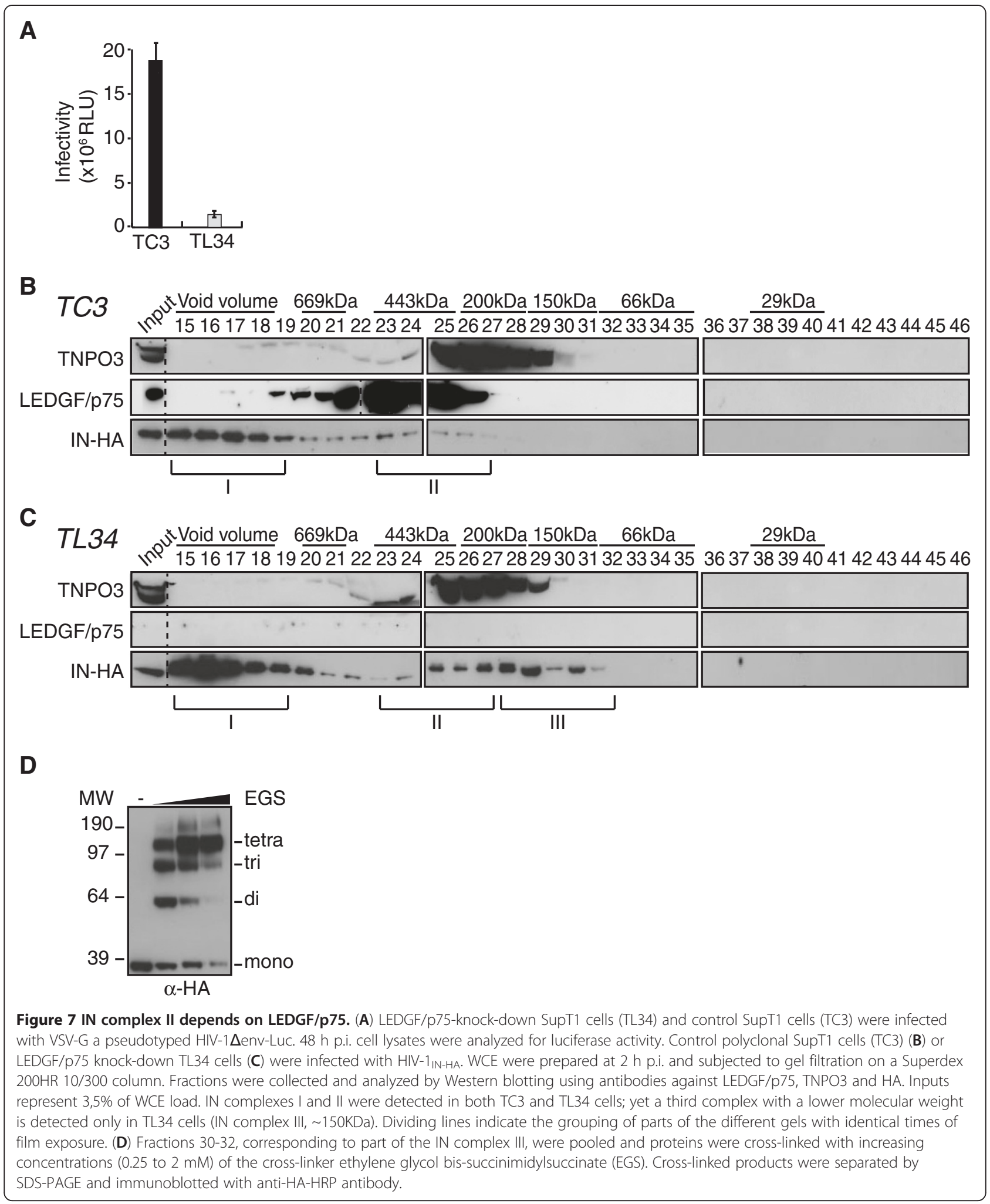




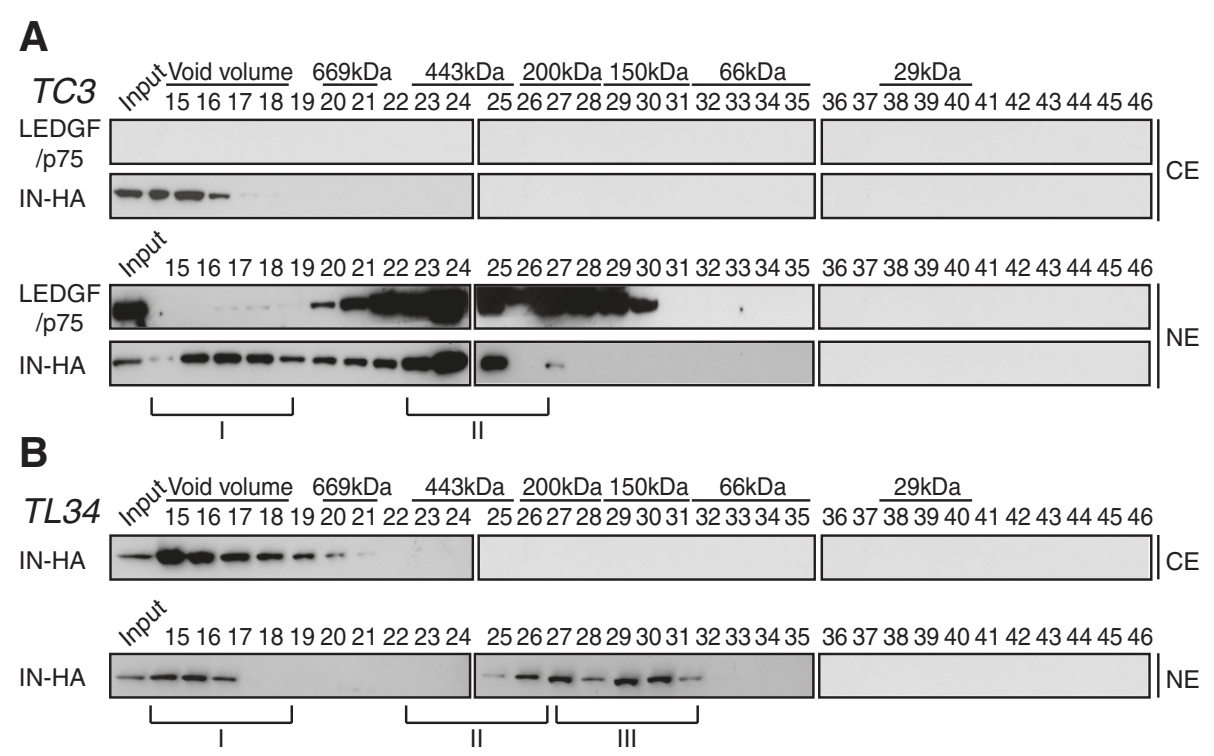

Figure 8 IN complex II and III are exclusively nuclear. Control SupT1 cells TC3 (A) and LEDGF/p75-knock-down SupT1 cells (TL34) (B) were infected with HIV-1 $1_{\text {IN-HA. }}$. Cytosolic and nuclear extracts (CE and NE, respectively) were prepared at $2 \mathrm{~h}$ p.i. and subjected to gel filtration on a Superdex 200HR 10/300 column. Fractions were collected and analyzed by Western blotting using antibodies against LEDGF/p75, or HA. Inputs represent 3,5\% of WCE load. LEDGF/p75 served as an internal control for the nuclear fraction in (A).

early phase of HIV-1 infection suggesting that, similar to the WT IN, this mutant was degraded by the proteasome (Figure 9A). Next, the interaction between IN and LEDGF/p75 was assessed in cells infected with HIV1 encoding wild type IN devoid of the HA tag, IN-HA or $\mathrm{IN}_{\mathrm{Q} 168 \mathrm{~A}}-\mathrm{HA}$. As expected, the Q168A mutation ablated the LEDGF/p75-IN interaction (Figure 9B). Surprisingly, fractionation of infected WCE indicated that $\mathrm{IN}_{\mathrm{Q} 168 \mathrm{~A}}$ failed to accumulate in low molecular weight complexes at $2 \mathrm{~h}$ and $6 \mathrm{~h}$ p.i. (Figure 9C). However, the high molecular weight complexes eluting in the void volume of the column (IN complex I) is still associated both with the cytoplasm and the nuclear fractions of the cells (Figure 9D). Taken together, these results indicated that the nuclear accumulation of IN complex II is impaired for a mutant defective for LEDGF/p75 interaction and tetramerization.

\section{Discussion}

Studies of retroviral pre-integration complexes have been hampered by the limited amounts available from infected cells. In this study, we took advantage of an infectious HIV-1 viral clone carrying a C-terminus HAtagged IN protein to explore IN low molecular weight complexes shortly after cell entry.

Our results show that IN undergoes rapid degradation by the proteasome shortly after its entry in the cytoplasm, whereas CA and MA remained stable. Previous published data showed that HIV-1 IN over-expressed in cells is actively degraded by the ubiquitin/proteasome system in both $\mathrm{N}$-end rule dependent and independent pathways [52,70,71,74-76]. Furthermore, the binding to LEDGF/p75 was shown to stabilize IN by preventing its degradation by the proteasome [52,75]. However, we observed a similar decrease of levels of the WT IN and the Q168A mutant impaired for LEDGF/p75 interaction. This is likely to reflect that at early steps of infection the vast majority of IN entering the cell cytoplasm is not yet accessible for LEDGF/p75 binding.

In preliminary studies aiming at analyzing the impact of HIV-1 infection on cellular cofactors complexes using a Superdex 200 10/300 GL column, we noticed that IN eluted in a low molecular weight complex that was distinct from the large IN-containing complex detected within the void volume of the gel filtration column. This large complex also co-eluted with viral DNA and integration activity, indicative of the presence of active PICs in these fractions. This observation is consistent with previous characterizations of retroviral nucleoprotein complexes in infected cells using gel filtration chromatography $[2,6,21,25]$. In contrast, the low molecular weight complex containing IN was devoid of viral cDNA and integrase activity. This complex was not observed in previous studies of HIV-1 PIC composition using gel filtration chromatography [21] or fractionation by sucrose gradient [77]. However, this is not surprising as these analyses were restricted to the cytoplasmic fraction of infected cells, precluding the detection of complex II that we found to be exclusively in the nuclear fraction. IN complex II could be similar to the one that was previously isolated from the nucleus of cells stably expressing 


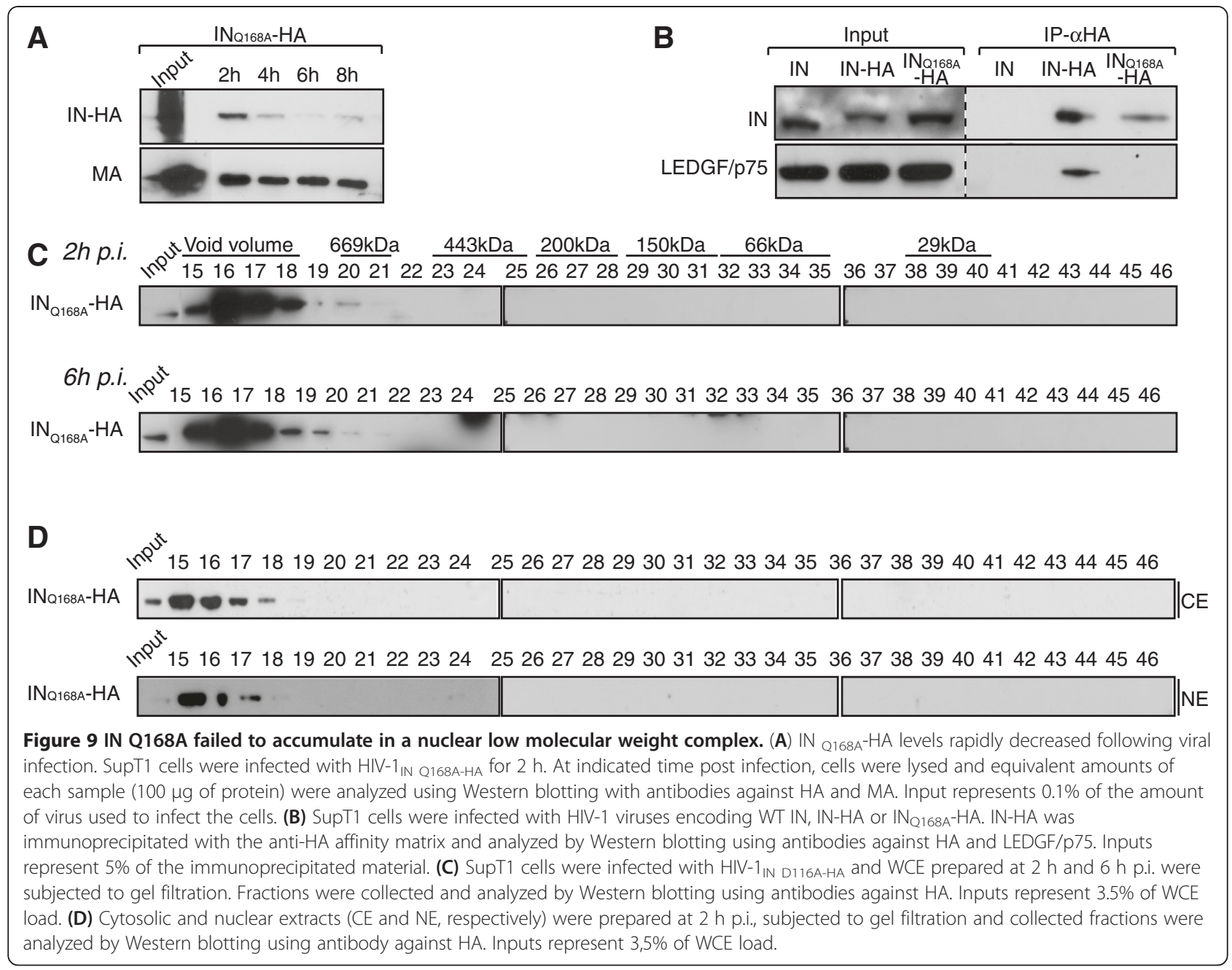

IN. In this report, tetramers of INs associated with LEDGF/p75 were found in a complex with an estimated mass around $400 \mathrm{KDa}$ [51]. Accordingly, we found that depletion of LEDGF/p75 lead to a shift towards a lower molecular weight complex (IN complex III) that peaks at $\sim 150 \mathrm{KDa}$ and contains tetramers of IN.

Non-exclusive hypothesis could explain the presence of IN in a low molecular weight complex distinct from the PIC. First, IN complex II could be the result of PIC destabilization. Indeed, the relative increase of the proportion of IN complex II at $6 \mathrm{~h}$ p.i. could reflect a dynamic shift of IN from active PICs to lower molecular weight complexes lacking full-length viral cDNA. Several mechanisms could account for the escape of IN from active PICs. Inefficient reverse transcription [78,79], or degradation of incoming viral cDNA by cytosolic exonucleases like TREX1 [80] could lead to the destabilization of PICs and the release of free IN. However, we did not observe a significant change in the distribution of IN complexes I and II upon inhibition of reverse transcription by the non-nucleoside reverse transcriptase inhibitor
Nevirapine, challenging the hypothesis that IN complex II formation is the result of abortive reverse transcription complexes. Moreover, a catalytic inactive mutant $\mathrm{IN}_{\mathrm{D} 116 \mathrm{~A}}$ accumulated in complex II suggesting that it is not the result of a post-integration event. Further experiments will be required to assess the potential role of cellular exonucleases in the release of low molecular weight IN complexes distinct from the PICs.

A second hypothesis posits that IN complex II might originate from IN molecules that are not associated with the PIC. IN is incorporated in virions as part of the GagPol polyprotein precursor, and it is generally admitted that between 30 to 100 of IN molecules are packaged per retroviral particle [81]. Although a precise quantification of IN incorporated into HIV-1 particles is still being awaited, it is likely that IN is present in large excess. Indeed, the functional intasome is formed by tetramer of IN tightly bound to the LTR ends of the newly synthesized viral cDNA $[82,83]$. Thus, this apparent excess of DNA-free IN could lead to the formation of IN complex II. Future experiments will reveal whether 
IN low molecular weight complexes play an active role during HIV-1 replication.

\section{Conclusions}

We show that, shortly after the virus enters the cell, a significant portion of IN distinct from active PICs forms a low molecular weight complex in the nucleus that is dependent on LEDGF/p75.

\section{Methods}

\section{Cells and viruses}

293 T cells were grown in DMEM plus glutamine, antibiotics and $10 \%$ decomplemented-FCS (foetal calf serum) (GibcoBRL, Invitrogen). SupT1, TC3 and TL34 cells were grown in RPMI 1640 plus glutamine, antibiotics and 10\% decomplemented-FCS (foetal calf serum) (GibcoBRL, Invitrogen). Virus stocks were generated by transfecting $293 \mathrm{~T}$ cells with either wild type or IN-HA tagged Lai molecular clone (HIV-1 $1_{\text {IN-HA }}$ [68]) using Fugene 6 reagent (Roche). HIV-1 ${ }_{\mathrm{IN}}$ Q168A-HA and HIV$1_{\text {IN D116A-HA }}$ were generated by site-directed mutagenesis using $\mathrm{HIV}-1_{\mathrm{IN}-\mathrm{HA}}$ as a template. Mutations were confirmed by sequencing and subcloned back into the PflMI sites of the WT HIV-1 IN-HA. HIV-1 $_{\text {Ienv Luc has }}$ been previously described [84]. VSV-G pseudotyped viruses were produced by co-transfecting $\mathrm{HIV}-1_{\mathrm{IN}-\mathrm{HA}}$ or HIV-1 $\Delta e n v$ Luc with plasmid pMD.G [85]. Twenty-four hours post-transfection, cells were washed with PBS and supernatants were collected at $48 \mathrm{~h}$ and $72 \mathrm{~h}$ post-transfection. The supernatants were $0.45-\mu \mathrm{m}$-filtered and ultracentrifuged at $150,000 \mathrm{~g}$ for $1 \mathrm{~h} 30$ minutes at $4^{\circ} \mathrm{C}$. Virus pellets from $30 \mathrm{ml}$ of supernatants were resuspended in $75 \mu \mathrm{l}$ of PBS. An equal volume of RPMI 1640 medium (GIBCO, Invitrogen) supplemented with 10\% fetal calf serum and antibiotics was added, and virus stocks were stored at $-80^{\circ} \mathrm{C}$. HIV-1 CAp24 antigen was quantified by ELISA (Innotests HIV Antigen mAb, Innogenetics, France).

\section{Cell infection and cell extract preparation}

SupT1 cells $\left(2 \times 10^{8}\right)$ were infected with $200 \mu \mathrm{g}$ of CAp24 (corresponding to a multiplicity of infectionMOI- of 5 , as quantified by real time PCR) of HIV-1 or HIV-1 IN-HA virus in a total volume of $500 \mu \mathrm{l}$ for $2 \mathrm{~h}$ at $37^{\circ} \mathrm{C}$. When indicated, $20 \mu \mathrm{M}$ of MG-132 was added along the course of infection. Two hours later, cells were washed three times in $25 \mathrm{ml}$ of PBS and resuspended in RPMI 1640 medium supplemented with 10\% fetal calf serum and antibiotics at a final concentration of $1.5 \times 10^{6}$ cells $/ \mathrm{ml}$. At different time post infection cells were harvested, washed twice with $25 \mathrm{ml}$ of PBS and lysed in 3 cell pellet volumes of lysis buffer (20 mM Tris- $\mathrm{HCl} \mathrm{pH} \mathrm{8.0,} 0.3 \mathrm{M} \mathrm{KCl}, 5 \mathrm{mM} \mathrm{MgCl}_{2}$, $10 \%(\mathrm{v} / \mathrm{v})$ glycerol, $0.1 \%$ tween 20, $1 \mathrm{mM}$ PMSF and protease inhibitor cocktail from Sigma). Cell lysis was completed by two successive rounds of freeze-thaw, then incubated for $30 \mathrm{~min}$ at $4^{\circ} \mathrm{C}$ on rotating wheel. Two successive centrifugation steps at $16,000 \mathrm{~g}$ for $30 \mathrm{~min}$ at $4^{\circ} \mathrm{C}$ allowed complete removal of insoluble materials. The collected supernatant corresponding to soluble proteins within the cells was called whole cell extracts (WCE). Cytosolic and nuclear extracts were obtained by sequential cell fractionation. Cells were first washed in buffer A (20 mM HEPES-KOH pH 7.9, $1.5 \mathrm{mM}$ $\mathrm{MgCl}_{2}, 10 \mathrm{mM} \mathrm{KCl}, 1 \mathrm{mM}$ PMSF and protease inhibitor cocktail from Sigma) and lysed 5 min on ice in 2 cell pellet volumes in buffer A and $0.1 \%(\mathrm{v} / \mathrm{v}) \mathrm{NP}-40$. After centrifugation of the cell lysate at $10,000 \mathrm{~g}$ for $5 \mathrm{~min}$, the supernatant corresponding to the cytosolic extract $(\mathrm{CE})$ was collected and the pellet was resuspended in 3 volumes of buffer B (20 mM HEPES-KOH pH 7.9, $1.5 \mathrm{mM} \mathrm{MgCl}_{2}$, $0.5 \mathrm{M} \mathrm{NaCl}, 25 \%$ (v/v) glycerol, $1 \mathrm{mM}$ PMSF and protease inhibitor cocktail from Sigma). After 15 minutes incubation on ice, the nuclear extract (NE) was collected by centrifugation for 15 minutes at $14,000 \mathrm{~g}$. CE and NE were stored at $-80^{\circ} \mathrm{C}$.

\section{PIC activity assay}

The assay is based on the quantification of integration events of viral cDNA into a parental vector (pTZ-19R) [8] with the following modifications. SupT1 cells were infected for $2 \mathrm{~h}$ with a VSV-G pseudotyped HIV-1 IN-HA virus and WCE were prepared at $6 \mathrm{~h}$ p.i. as previously described. WCE (3 mg) were injected into Superdex 200 10/300 GL gel filtration column. Each fraction was collected and treated with RNase A (final concentration at $20 \mu \mathrm{g} / \mathrm{ml}$ ) for 20 minutes at RT in a final volume of $250 \mu$ l. Integration reaction assay was performed at $37^{\circ} \mathrm{C}$ for 45 minutes by mixing each fraction with $1 \mu \mathrm{g}$ of target plasmid pTZ-19R in integrase reaction buffer (INRB: $20 \mathrm{mM}$ HEPES-KOH pH 7.4, $150 \mathrm{mM} \mathrm{KCl}, 1 \mathrm{mM}$ $\mathrm{MgCl}_{2}, 4 \%$ glycerol, and $1 \mathrm{mM}$ DTT added just before starting the reaction) in a final volume of $350 \mu \mathrm{l}$. For each fraction, negative control was performed by omitting the target plasmid in the integration reaction assay. The reaction was stopped by adding 0.5\% SDS, $8 \mathrm{mM}$ EDTA and $0.5 \mathrm{mg} / \mathrm{ml}$ proteinase $\mathrm{K}$ for $1 \mathrm{~h}$ at $56^{\circ} \mathrm{C}$. DNA was then extracted with phenol and phenol:chloroform: isoamylalcohol 25:24:1, using glycogen as carrier, and stored at $-20^{\circ} \mathrm{C}$. Integration events were quantified using a two-step PCR reaction. In the first round PCR, integrated HIV-1 sequences were amplified using the HIV-1 specific LM667 primer [78] together with primers annealing to opposite strand of pTZ-19R in tail-to-tail fashion. TZ2414 primer sequence is $5^{\prime}$ - GTTGTTCCAGTTTG GAACAAGAGTC-3'. TZ2413 primer sequence is $5^{\prime}$ ACTCAACCCTATCTCGGTCTATTC-3'. To evidence background PCR signal, TZ2414 and TZ2413 primers 
were omitted from each integration reaction. We performed the second nested-PCR steps using conditions previously described [78]. Results shown are indicated as relative units of specific signal (signal from PCR with target and with TZ2414/TZ2413 primers) minus unspecific signal (signal from PCR without target or without TZ2414/TZ2413 primers). The copy number of integrated DNA was determined in reference to a standard curve obtained by concomitant two steps amplification of serial dilution of the standard pNLX-HIVLTR vector. This construct was generated by amplifying the LTR region (n.t. 1-702, numbering based on NL4.3 sequence) and cloning into BamH1 and Pst1 restriction endonuclease sites of pTZ-19R.

\section{Quantification of viral cDNA by real-time PCR}

Prior to infection, viral stocks were treated $1 \mathrm{~h}$ at $37^{\circ} \mathrm{C}$ with $100 \mathrm{U}$ per $\mathrm{ml}$ of DNAseI (Roche applied Science). SupT1 cells $\left(6 \times 10^{6}\right)$ were infected with viral doses corresponding to $6 \mu \mathrm{g}$ of HIV-1 $1_{\text {IN-HA }}$ CAp24 antigen in 12wells plates. At $2 \mathrm{~h}$ p.i., cells were washed twice in PBS. At $2 \mathrm{~h}, 4 \mathrm{~h}, 6 \mathrm{~h}, 8 \mathrm{~h}$ and $10 \mathrm{~h}$ p.i. cells were harvested, washed twice in PBS and DNA was extracted using the QIAamp Blood DNA Minikit (Qiagen). Quantifications of viral DNA were performed by real-time PCR using the LightCycler 480 system (Roche Applied Science). Primers, probes and PCR run conditions were described previously [84]. The copy numbers of HIV-1 late reverse transcription product (LRT) and 2-LTR circles were determined using standard curves obtained by amplification of cloned DNA containing the matched sequences. The copy number of integrated HIV-1 DNA was determined in reference to a standard curve generated by concomitant two-stage PCR amplification of a serial dilution of the standard HeLa HIVR7-Neo cell DNA [78]. Copy numbers of each viral form were normalized with the number of cells obtained by the quantification by PCR of the $\beta$-globin gene according to the manufacturer instructions (Roche Applied Science).

\section{Immunoprecipitation}

For co-immunoprecipitation experiments, $3 \mathrm{mg}$ of WCE were mixed with $50 \mu \mathrm{l}$ ( $50 \%$ slurry) of anti-HA affinity matrix (clone 3 F10, Roche Applied Science) supplemented with protease inhibitor cocktail and $1 \mathrm{mM}$ PMSF for $3 \mathrm{~h}$ at $4^{\circ} \mathrm{C}$ on rotating wheel. Beads were washed three times with 15 volumes PBS- $0.1 \%$ tween 20 for 5 minutes on a rotating wheel at $4^{\circ} \mathrm{C}$. IN-HA complexes were directly resuspended in $1 \times$ loading sample buffer and boiled for $5 \mathrm{~min}$.

\section{Chromatography}

Whole cell extracts were subjected to size exclusion chromatography at $4^{\circ} \mathrm{C}$ using an AKTA purifier system
(GE Healthcare). Four mg of WCE were injected on a Superdex 200 10/300 GL column and $400 \mu$ fractions were collected at a flow rate of $0.5 \mathrm{ml} / \mathrm{min}$ of WCE buffer. Proteins were precipitated over-night at $4^{\circ} \mathrm{C}$ in $10 \%$ trichloroacetic acid, washed twice in cold acetone and analyzed by Western blotting. Protein standards (Sigma) were fractionated under same conditions to estimate the size of the eluted protein complexes. When required, DNA was extracted from each fraction using the QIAamp Blood DNA Minikit (Qiagen).

\section{Cross-linking}

Cross-linking reactions were performed on gel filtration fractions collected in $20 \mathrm{mM}$ HEPES-KOH pH 7.2, $0.3 \mathrm{M} \mathrm{KCl}, 5 \mathrm{mM} \mathrm{MgCl} 2,10 \%$ glycerol, $0.1 \%$ tween 20 , $1 \mathrm{mM}$ PMSF and protease inhibitor cocktail (Sigma). Fractions 30-32, corresponding to part of IN complex III, were pooled and proteins were cross-linked with $0.25 \mathrm{mM}$ to $2 \mathrm{mM}$ of the cross-linker ethylene glycol bis-succinimidylsuccinate (EGS, freshly prepared) for 30 minutes at room temperature. The reaction was stopped by adding Tris- $\mathrm{HCl} \mathrm{pH} 7.5$ at a final concentration of $50 \mathrm{mM}$ for 15 minutes at room temperature.

\section{SDS-Page and Western-blotting}

Proteins were separated by $4-12 \%$ gradient SDS-PAGE (Invitrogen), transferred onto nitrocellulose membranes, and revealed by Western-blotting using the following antibodies as indicated: anti-CAp24 (AIDS Research and Reference Reagent Program), anti-IN (Santa Cruz), antiMA (Hybridolab), anti-HA-HRP (clone 3 F10, Roche Applied Science), LEDGF/p75 (BD Bioscience), TNPO3 (Abcam), and $\alpha$-tubulin (Sigma-Aldrich).

\section{Competing interests}

The authors declare that they have no competing interests.

\section{Authors' contributions}

$A G, M B$ and SE designed experiments; AG, NS, ES and SE performed experiments; AG, NS and SE analyzed the data; AG and SE wrote the paper, and $A G, N S$ and SE commented and corrected on manuscript drafts. All authors read and approved the final manuscript.

\section{Acknowledgments}

We are grateful to Fabrizzio Mammano (Inserm U941, Paris, France) for the generous gift of the pBru IN-HA plasmid, to Eric Poeschla (Mayo Clinic, Rochester, Minnesota, USA) for the generous gift of the TC3 and TL34 cell lines, to Clarisse Berlioz-Torrent, Sarah Gallois-Montbrun and Lisa Hayden for critical reading of the manuscript, and to Jean-Luc Darlix and all members of the Berlioz-Emiliani laboratory for helpful discussions. The following reagent was obtained through the AIDS Research and Reference Reagent Program, Division of AIDS, NIAID, NIH: HIV-1 SF2 $_{2}$ P24 Antiserum. We thank the Genome and sequencing research facility from Institut Cochin.

This work was supported by grants from the Agence Nationale de la Recherche sur le Sida et les Hépatites (ANRS) and Agence Nationale de la Recherche (ANR) [ANR-06-RIB-021-02, ANR-09-BIOT-006-02] to SE.. A.G. was recipient of postdoctoral fellowships from ANRS and SIDACTION. N.S. was recipient of a postdoctoral fellowship from ANRS. 


\section{Author details}

${ }^{1}$ Inserm, U1016, Institut Cochin, Paris, France. ${ }^{2}$ Cnrs, UMR8104, Paris, France. ${ }^{3}$ Université Paris Descartes, Paris, France. ${ }^{4}$ Department of Medical Microbiology and Immunology, Creighton University School of Medicine, Omaha, NE, USA. ${ }^{5}$ The Nebraska Center for Virology, Lincoln, NE, USA.

Received: 29 June 2012 Accepted: 3 January 2013

Published: 1 February 2013

\section{References}

1. Nisole S, Saib A: Early steps of retrovirus replicative cycle. Retrovirology 2004, 1:9.

2. Bowerman B, Brown PO, Bishop JM, Varmus HE: A nucleoprotein complex mediates the integration of retroviral DNA. Genes Dev 1989, 3:469-478.

3. Brown PO, Bowerman B, Varmus HE, Bishop JM: Correct integration of retroviral DNA in vitro. Cell 1987, 49:347-356.

4. Fujiwara T, Mizuuchi K: Retroviral DNA integration: structure of an integration intermediate. Cell 1988, 54:497-504

5. Ellison V, Abrams H, Roe T, Lifson J, Brown P: Human immunodeficiency virus integration in a cell-free system. J Virol 1990, 64:2711-2715.

6. Farnet CM, Haseltine WA: Integration of human immunodeficiency virus type 1 DNA in vitro. Proc Natl Acad Sci U S A 1990, 87:4164-4168.

7. Hansen MS, Bushman FD: Human immunodeficiency virus type 2 preintegration complexes: activities in vitro and response to inhibitors. J Virol 1997, 71:3351-3356.

8. Engelman A: Isolation and analysis of HIV-1 preintegration complexes. Methods Mol Biol 2009, 485:135-149.

9. Bushman FD, Fujiwara T, Craigie R: Retroviral DNA integration directed by HIV integration protein in vitro. Science 1990, 249:1555-1558.

10. Craigie R, Fujiwara T, Bushman F: The IN protein of Moloney murine leukemia virus processes the viral DNA ends and accomplishes their integration in vitro. Cell 1990, 62:829-837.

11. Engelman A, Mizuuchi K, Craigie R: HIV-1 DNA integration: mechanism of viral DNA cleavage and DNA strand transfer. Cell 1991, 67:1211-1221.

12. Chen $\mathrm{H}$, Wei $\mathrm{SQ}$, Engelman $\mathrm{A}$ : Multiple integrase functions are required to form the native structure of the human immunodeficiency virus type I intasome. J Biol Chem 1999, 274:17358-17364.

13. Wei SQ, Mizuuchi K, Craigie R: A large nucleoprotein assembly at the ends of the viral DNA mediates retroviral DNA integration. EMBO J 1997. 16:7511-7520.

14. Wei SQ, Mizuuchi K, Craigie R: Footprints on the viral DNA ends in moloney murine leukemia virus preintegration complexes reflect a specific association with integrase. Proc Natl Acad Sci U S A 1998, 95:10535-10540

15. Brown PO, Bowerman B, Varmus HE, Bishop JM: Retroviral integration: structure of the initial covalent product and its precursor, and a role for the viral IN protein. Proc Natl Acad Sci U S A 1989, 86:2525-2529.

16. Pauza CD: Two bases are deleted from the termini of HIV-1 linear DNA during integrative recombination. Virology 1990, 179:886-889.

17. Yoder KE, Bushman FD: Repair of gaps in retroviral DNA integration intermediates. J Virol 2000, 74:11191-11200.

18. Vincent KA, York-Higgins D, Quiroga M, Brown PO: Host sequences flanking the HIV provirus. Nucleic Acids Res 1990, 18:6045-6047.

19. Bukrinsky MI, Sharova N, McDonald TL, Pushkarskaya T, Tarpley WG, Stevenson M: Association of integrase, matrix, and reverse transcriptase antigens of human immunodeficiency virus type 1 with viral nucleic acids following acute infection. Proc Natl Acad Sci U S A 1993, 90:6125-6129.

20. Farnet CM, Bushman FD: HIV-1 cDNA integration: requirement of HMG I (Y) protein for function of preintegration complexes in vitro. Cell 1997, 88:483-492.

21. Farnet $\mathrm{CM}$, Haseltine WA: Determination of viral proteins present in the human immunodeficiency virus type 1 preintegration complex. J Virol 1991, 65:1910-1915.

22. Gallay P, Swingler S, Song J, Bushman F, Trono D: HIV nuclear import is governed by the phosphotyrosine-mediated binding of matrix to the core domain of integrase. Cell 1995, 83:569-576.

23. Iordanskiy S, Berro R, Altieri M, Kashanchi F, Bukrinsky M: Intracytoplasmic maturation of the human immunodeficiency virus type 1 reverse transcription complexes determines their capacity to integrate into chromatin. Retrovirology 2006, 3:4
24. Karageorgos L, Li P, Burrell C: Characterization of HIV replication complexes early after cell-to-cell infection. AIDS Res Hum Retroviruses 1993, 9:817-823.

25. Miller MD, Farnet CM, Bushman FD: Human immunodeficiency virus type 1 preintegration complexes: studies of organization and composition J Virol 1997, 71:5382-5390.

26. Li L, Yoder K, Hansen MS, Olvera J, Miller MD, Bushman FD: Retroviral cDNA integration: stimulation by HMG I family proteins. J Virol 2000, 74:10965-10974

27. Li L, Olvera JM, Yoder KE, Mitchell RS, Butler SL, Lieber M, Martin SL, Bushman FD: Role of the non-homologous DNA end joining pathway in the early steps of retroviral infection. EMBO J 2001, 20:3272-3281.

28. Lin CW, Engelman A: The barrier-to-autointegration factor is a component of functional human immunodeficiency virus type 1 preintegration complexes. J Virol 2003, 77:5030-5036.

29. Llano M, Vanegas M, Fregoso O, Saenz D, Chung S, Peretz M, Poeschla EM: LEDGF/p75 determines cellular trafficking of diverse lentiviral but not murine oncoretroviral integrase proteins and is a component of functional lentiviral preintegration complexes. J Viro/ 2004, 78:9524-9537.

30. Suzuki Y, Craigie R: The road to chromatin - nuclear entry of retroviruses. Nat Rev Microbiol 2007, 5:187-196.

31. Arhel NJ, Souquere-Besse S, Munier S, Souque P, Guadagnini S, Rutherford S, Prevost MC, Allen TD, Charneau P: HIV-1 DNA Flap formation promotes uncoating of the pre-integration complex at the nuclear pore. EMBO 2007, 26:3025-3037.

32. Zennou V, Petit C, Guetard D, Nerhbass U, Montagnier L, Charneau P: HIV-1 genome nuclear import is mediated by a central DNA flap. Cell 2000, 101:173-185.

33. Yamashita M, Emerman M: The cell cycle independence of HIV infections is not determined by known karyophilic viral elements. PLOS Pathog 2005, 1:e18.

34. Yamashita M, Perez O, Hope TJ, Emerman M: Evidence for direct involvement of the capsid protein in HIV infection of nondividing cells. PLoS Pathog 2007, 3:1502-1510.

35. Brass AL, Dykxhoorn DM, Benita Y, Yan N, Engelman A, Xavier RJ, Lieberman J, Elledge SJ: Identification of host proteins required for HIV infection through a functional genomic screen. Science 2008, 319:921-926.

36. Christ F, Thys W, De Rijck J, Gijsbers R, Albanese A, Arosio D, Emiliani S, Rain JC, Benarous R, Cereseto A, Debyser Z: Transportin-SR2 imports HIV into the nucleus. Curr Biol 2008, 18:1192-1202.

37. Konig R, Zhou Y, Elleder D, Diamond TL, Bonamy GM, Irelan JT, Chiang CY, Tu $B P$, De Jesus PD, Lilley CE, et al: Global analysis of host-pathogen interactions that regulate early-stage HIV-1 replication. Cell 2008, 135:49-60.

38. De laco A, Luban J: Inhibition of HIV-1 infection by TNPO3 depletion is determined by capsid and detectable after viral cDNA enters the nucleus. Retrovirology 2011, 8:98.

39. Schaller T, Ocwieja KE, Rasaiyaah J, Price AJ, Brady TL, Roth SL, Hue S, Fletcher AJ, Lee K, Kewalramani VN, et al: HIV-1 capsid-cyclophilin interactions determine nuclear import pathway. Integration targeting and replication efficiency. PLoS Pathog 2011, 7:e1002439.

40. Zhou L, Sokolskaja E, Jolly C, James W, Cowley SA, Fassati A: Transportin 3 promotes a nuclear maturation step required for efficient HIV-1 integration. PLoS Pathog 2011, 7:e1002194.

41. Kataoka N, Bachorik JL, Dreyfuss G: Transportin-SR, a nuclear import receptor for SR proteins. J Cell Biol 1999, 145:1145-1152.

42. Rain JC, Cribier A, Gerard A, Emiliani S, Benarous R: Yeast two-hybrid detection of integrase-host factor interactions. Methods 2009, 47:291-297.

43. Cribier A, Segeral E, Delelis O, Parissi V, Simon A, Ruff M, Benarous R, Emiliani S: Mutations affecting interaction of integrase with TNPO3 do not prevent HIV-1 cDNA nuclear import. Retrovirology 2011, 8:104.

44. Krishnan L, Matreyek KA, Oztop I, Lee K, Tipper CH, Li X, Dar MJ, Kewalramani VN, Engelman A: The requirement for cellular transportin 3 (TNPO3 or TRN-SR2) during infection maps to human immunodeficiency virus type 1 capsid and not integrase. J Virol 2010, 84:397-406.

45. Thys W, De Houwer S, Demeulemeester J, Taltynov O, Vancraenenbroeck R, Gerard M, De Rijck J, Gijsbers R, Christ F, Debyser Z: Interplay between HIV entry and transportin-SR2 dependency. Retrovirology 2011, 8:7.

46. Cherepanov P, Maertens GN, Hare S: Structural insights into the retroviral DNA integration apparatus. Curr Opin Struct Biol 2011, 21:249-256.

47. Li X, Krishnan L, Cherepanov P, Engelman A: Structural biology of retroviral DNA integration. Virology 2011, 411:194-205. 
48. Ciuffi A, Llano M, Poeschla E, Hoffmann C, Leipzig J, Shinn P, Ecker JR, Bushman F: A role for LEDGF/p75 in targeting HIV DNA integration. Nat Med 2005, 11:1287-1289.

49. Marshall HM, Ronen K, Berry C, Llano M, Sutherland H, Saenz D, Bickmore W, Poeschla E, Bushman FD: Role of PSIP1/LEDGF/p75 in lentiviral infectivity and integration targeting. PLoS One 2007, 2:e1340.

50. Shun MC, Raghavendra NK, Vandegraaff N, Daigle JE, Hughes S, Kellam P, Cherepanov $P$, Engelman A: LEDGF/p75 functions downstream from preintegration complex formation to effect gene-specific HIV-1 integration. Genes Dev 2007, 21:1767-1778.

51. Cherepanov P, Maertens G, Proost P, Devreese B, Van Beeumen J, Engelborghs $Y$, De Clercq E, Debyser Z: HIV-1 integrase forms stable tetramers and associates with LEDGF/p75 protein in human cells. J Biol Chem 2003, 278:372-381.

52. Emiliani S, Mousnier A, Busschots K, Maroun M, Van Maele B, Tempe D, Vandekerckhove L, Moisant F, Ben-Slama L, Witvrouw M, et al: Integrase mutants defective for interaction with LEDGF/p75 are impaired in chromosome tethering and HIV-1 replication. J Biol Chem 2005, 280:25517-25523.

53. Turlure F, Devroe E, Silver PA, Engelman A: Human cell proteins and human immunodeficiency virus DNA integration. Front Biosci 2004, 9:3187-3208.

54. Ge H, Roeder RG: Purification, cloning, and characterization of a human coactivator, PC4, that mediates transcriptional activation of class II genes. Cell 1994, 78:513-523.

55. Ge H, Si Y, Roeder RG: Isolation of CDNAs encoding novel transcription coactivators $\mathrm{p} 52$ and p75 reveals an alternate regulatory mechanism of transcriptional activation. EMBO J 1998, 17:6723-6729.

56. Yokoyama A, Cleary ML: Menin critically links MLL proteins with LEDGF on cancer-associated target genes. Cancer Cell 2008, 14:36-46.

57. Engelman $A$, Cherepanov $P$ : The lentiviral integrase binding protein LEDGF/p75 and HIV-1 replication. PLoS Pathog 2008, 4:e1000046.

58. Poeschla EM: Integrase, LEDGF/p75 and HIV replication. Cell Mol Life Sci 2008, 65:1403-1424.

59. Busschots K, Voet A, De Maeyer M, Rain JC, Emiliani S, Benarous R, Desender L, Debyser Z, Christ F: Identification of the LEDGF/p75 binding site in HIV1 integrase. J Mol Biol 2007, 365:1480-1492.

60. Cherepanov P, Sun ZY, Rahman S, Maertens G, Wagner G, Engelman A: Solution structure of the HIV-1 integrase-binding domain in LEDGF/p75. Nat Struct Mol Biol 2005, 12:526-532.

61. Rahman S, Lu R, Vandegraaff N, Cherepanov P, Engelman A: Structurebased mutagenesis of the integrase-LEDGF/p75 interface uncouples a strict correlation between in vitro protein binding and HIV-1 fitness. Virology 2007, 357:79-90.

62. De Rijck J, Vandekerckhove L, Gijsbers R, Hombrouck A, Hendrix J, Vercammen J, Engelborghs Y, Christ F, Debyser Z: Overexpression of the lens epithelium-derived growth factor/p75 integrase binding domain inhibits human immunodeficiency virus replication. J Virol 2006, 80:11498-11509.

63. Llano M, Vanegas M, Hutchins N, Thompson D, Delgado S, Poeschla EM: Identification and characterization of the chromatin-binding domains of the HIV-1 integrase interactor LEDGF/p75. J Mol Biol 2006, 360:760-773.

64. Vandekerckhove L, Christ F, Van Maele B, De Rijck J, Gijsbers R, Van den Haute C, Witvrouw M, Debyser Z: Transient and stable knockdown of the integrase cofactor LEDGF/p75 reveals its role in the replication cycle of human immunodeficiency virus. J Virol 2006, 80:1886-1896.

65. Zielske SP, Stevenson M: Modest but reproducible inhibition of human immunodeficiency virus type 1 infection in macrophages following LEDGFp75 silencing. J Virol 2006, 80:7275-7280.

66. Cherepanov P, Ambrosio AL, Rahman S, Ellenberger T, Engelman A: Structural basis for the recognition between HIV-1 integrase and transcriptional coactivator p75. Proc Natl Acad Sci U S A 2005, 102:17308-17313.

67. Hare S, Shun MC, Gupta SS, Valkov E, Engelman A, Cherepanov P: A novel co-crystal structure affords the design of gain-of-function lentiviral integrase mutants in the presence of modified PSIP1/LEDGF/p75. PLOS Pathog 2009, 5:e1000259.

68. Petit $\mathrm{C}$, Schwartz O, Mammano F: Oligomerization within virions and subcellular localization of human immunodeficiency virus type 1 integrase. J Virol 1999, 73:5079-5088.
69. Gabuzda DH, Lawrence K, Langhoff E, Terwilliger E, Dorfman T, Haseltine WA, Sodroski J: Role of vif in replication of human immunodeficiency virus type 1 in CD4+ T lymphocytes. J Virol 1992, 66:6489-6495.

70. Mulder LC, Muesing MA: Degradation of HIV-1 integrase by the $\mathrm{N}$-end rule pathway. J Biol Chem 2000, 275:29749-29753.

71. Mousnier A, Kubat N, Massias-Simon A, Segeral E, Rain JC, Benarous R, Emiliani S, Dargemont C: von Hippel Lindau binding protein 1-mediated degradation of integrase affects HIV-1 gene expression at a postintegration step. Proc Natl Acad Sci U S A 2007, 104:13615-13620.

72. Llano M, Saenz DT, Meehan A, Wongthida P, Peretz M, Walker WH, Teo W, Poeschla EM: An essential role for LEDGF/p75 in HIV integration. Science 2006, 314:461-464.

73. Li X, Koh Y, Engelman A: Correlation of recombinant integrase activity and functional preintegration complex formation during acute infection by replication-defective integrase mutant human immunodeficiency virus. J Virol 2012, 86:3861-3879.

74. Devroe E, Engelman A, Silver PA: Intracellular transport of human immunodeficiency virus type 1 integrase. J Cell Sci 2003, 116:4401-4408.

75. Llano M, Delgado S, Vanegas M, Poeschla EM: Lens epithelium-derived growth factor/p75 prevents proteasomal degradation of HIV-1 integrase. J Biol Chem 2004, 279:55570-55577.

76. Tasaki T, Mulder LC, Iwamatsu A, Lee MJ, Davydov IV, Varshavsky A, Muesing M, Kwon YT: A family of mammalian E3 ubiquitin ligases that contain the UBR box motif and recognize N-degrons. Mol Cell Biol 2005, 25:7120-7136.

77. Gallay P, Swingler S, Aiken C, Trono D: HIV-1 infection of nondividing cells: C-terminal tyrosine phosphorylation of the viral matrix protein is a key regulator. Cell 1995, 80:379-388.

78. Brussel A, Sonigo P: Analysis of early human immunodeficiency virus type 1 DNA synthesis by use of a new sensitive assay for quantifying integrated provirus. J Virol 2003, 77:10119-10124.

79. Thomas JA, Ott DE, Gorelick RJ: Efficiency of human immunodeficiency virus type 1 postentry infection processes: evidence against disproportionate numbers of defective virions. J Virol 2007, 81:4367-4370.

80. Yan N, Regalado-Magdos AD, Stiggelbout B, Lee-Kirsch MA, Lieberman J: The cytosolic exonuclease TREX1 inhibits the innate immune response to human immunodeficiency virus type 1. Nat Immunol 2010, 11:1005-1013.

81. Swanstrom R, Wills JW: Synthesis, assembly, and processing of viral proteins. In Retroviruses. Edited by Coffin JM. Plainview, New York: Cold Spring Harbor Laboratory Press; 1997:263-334.

82. Hare S, Gupta SS, Valkov E, Engelman A, Cherepanov P: Retroviral intasome assembly and inhibition of DNA strand transfer. Nature 2010, 464:232-236.

83. Krishnan L, Li X, Naraharisetty HL, Hare S, Cherepanov P, Engelman A: Structure-based modeling of the functional HIV-1 intasome and its inhibition. Proc Natl Acad Sci U S A 2010, 107:15910-15915.

84. Maroun M, Delelis O, Coadou G, Bader T, Segeral E, Mbemba G, Petit C, Sonigo P, Rain JC, Mouscadet JF, et al: Inhibition of early steps of HIV-1 replication by SNF5/Ini1. J Bio/ Chem 2006, 281:22736-22743.

85. Naldini L, Blomer U, Gage FH, Trono D, Verma IM: Efficient transfer, integration, and sustained long-term expression of the transgene in adult rat brains injected with a lentiviral vector. Proc Natl Acad Sci U S A 1996, 93:11382-11388.

doi:10.1186/1742-4690-10-13

Cite this article as: Gérard et al:: Identification of low molecular weight nuclear complexes containing integrase during the early stages of HIV-1 infection. Retrovirology 2013 10:13. 